\title{
Micropropagation of Paulownia taiwaniana from mature tissues
}

\author{
J.C. Yang, S.H. Chang and C.K. Ho
}

Silviculture Division, Taiwan Forestry Research Institute, 53 Nan-Hai Rd., Taipei 10728, Taiwan, R.O.C.

\section{Introduction}

Paulownia taiwaniana is an important agroforestry species in Taiwan. However, witches' broom has impaired the reforestation program for many years. The search for disease-free individuals in infected plantations and then multiplying them by means of shoot-tip culture is part of our pest management program. This paper reports the appropriate techniques to produce disease-free plants from mature tissues of $P$. taiwaniana.

\section{Materials and Methods}

The apices of small branches and their lateral shoots which emerged after the removal of branch tips were excised from an $8 \mathrm{yr}$ old tree of $P$. taiwaniana. Both meristem tissues, $0.5-0.8 \mathrm{~cm}$ long, were cleaned under running tap water for $30 \mathrm{~min}$, followed by sterilization in $70 \%$ ethanol for $30 \mathrm{~s}$ and then in $0.5 \%$ sodium hypochlorite in a supersonic vibrator for $10 \mathrm{~min}$. Finally the tissues were washed 3 times in sterile distilled water.

The sterilized explants were first cultured on solid and liquid Murashige and Skoog (1962) MS basic media with full, $1 / 2$ and $1 / 3$ strength and supplemented with $0.1-15 \mathrm{mg} / 16$-benzyl- aminopurine (BA) or kinetin for the induction of multishoots. The individual stems separated from multishoots were then transferred onto the same MS basic medium, but supplemented with 0-4 mg/ 2-naphthalene acetic acid (NAA) or indole-3-butyric acid (IBA) for root formation. All cultures were incubated at $25 \pm 2^{\circ} \mathrm{C}$ with a $10 \mathrm{~h}$ photoperiod and light intensity of 65-75 $\mu \mathrm{mol} \cdot \mathrm{s}^{-1} \cdot \mathrm{m}^{-2}$.

\section{Results and Discussion}

After 7 days of incubation in MS medium, the survival rate of lateral shoots was $99 \%$, while branch apices became brown and finally died, indicating that rejuvenation by means of trimming branches may improve the survival and overcome tissue browning, as pointed out by Franclet (1981). The multiplication and growth of new shoots did not exhibit marked differences among the 3 strengths of MS media, which is in contrast to the recommendation of using a low salt medium as the base formulation for woody plants, given by McCown and Sellmer (1987).

High level (15 ppm) BA stimulated $92.5 \%$ of the explants to form multishoots in both solid and liquid MS. However, the proliferation of new shoots from every 


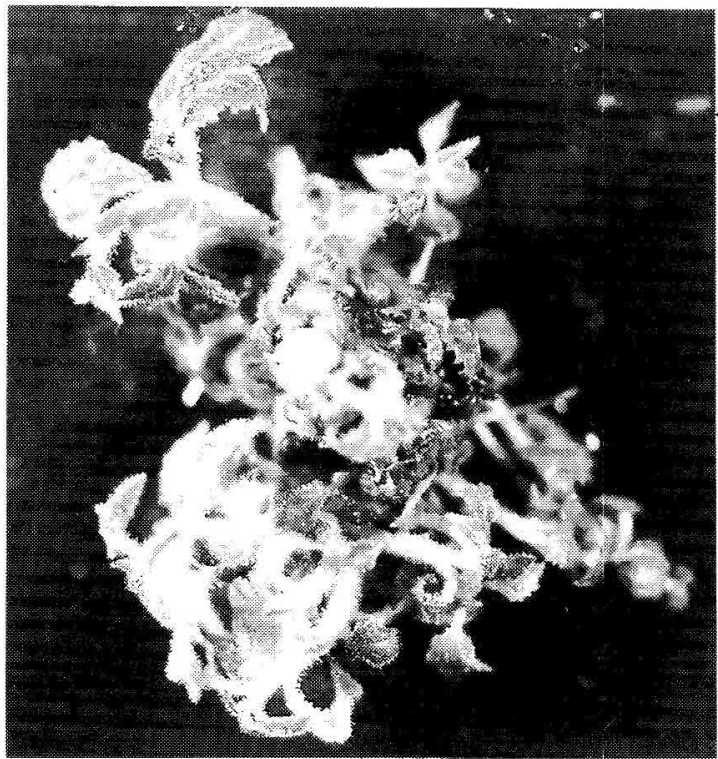

Fig. 1. Mutishoot with more than 50 buds derived from an axillary bud of an 8 yr old Paulownia taiwaniana when cultured in solid MS +15 mg/l BA for $45 \mathrm{~d}$.

explant in solid MAS (>50) (Fig. 1) was much higher than in liquid MS (only 10). Kinetin did not effectively induce multishoot iormation as described by Wang and $\mathrm{Hu}(1980)$. It is interesting to note that the regeneration capability of mature tis-
Sue from $P$. tawaniana coluld be comparable to that of juvenile tissue from the same species (Ho et al., 1988), however, the patterns of differentiation for each were different. The former reproduced multishoots directly from explants, while

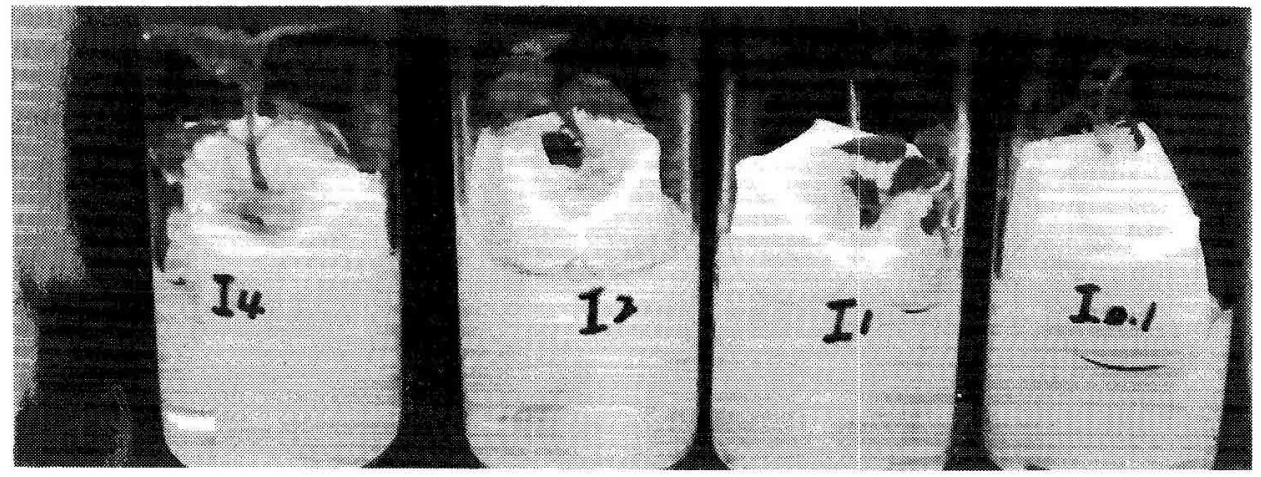

Fig. 2. Root formation of in vitro shoots when cultured on the filter paper bridge in liquid MS with different levels of IBA. 
the latter regenerated multishoots via callus and, hence, some variations might occur.

The in vitro shoots carrying 2 tiny leaves and a stem node about $1 \mathrm{~cm}$ long were cultured on the filter paper bridge in liquid MS containing $4 \mathrm{ppm}$ IBA. A satisfactory rooting rate of $88.9 \%$ and an average 9.4 roots/shoot were obtained (Fig. 2). All of the rooted shoots survived and became healthy plantlets for field planting trials or infection experiments. The use of a filter paper bridge in liquid MS medium confirmed the reasons given by $\mathrm{Hu}$ and Wang (1983) that it may facilitate the diffusion of certain toxic substances which extrude from the in vitro shoots and, hence, improve rooting and survival of plantlets.

\section{Conclusions}

The most suitable explant for micropropagation of mature $P$. taiwaniana is the axillary bud which emerges after the removal of the branch apical meristem.

The multiplication and growth of in vitro shoots can be effectively enhanced by adding 15 ppm BA to solid MS culture medium.

Satisfactory rooting can be obtained when the in vitro shoots carrying 2 tiny leaves and a stem node about $1 \mathrm{~cm}$ long are cultured on a filter paper bridge in liquid MS.

\section{Acknowledgments}

This research was supported by a grant from the National Science Council of the Republic of China in Taiwan.

\section{References}

Franclet A. (1981) Rajeunissement et micropropagation des ligneux. In: Proc. IUFRO Sect. S2.01.5. Int. Workshop in Vitro Cultivation For. Tree Species, Fontainebleau, France, pp. 55-64 Ho C.K., Chang S.H. \& Yang J.C. (1988) Tissue culture of Paulownia taiwaniana from juvenile tissue. Paper presented at Symp. on Tree Improv. and Tissue Culture, Experimental Forest of National Taiwan University, Chi-tou, 17-19 May 1988, pp. 16-18

Hu C.Y. \& Wang P.J. (1983) Meristem, shoot tip, and bud cultures. In: Handbook of Plant Cell Culture, Vol. I. Techniques for Propagation and Breeding. (Evans D.A., et al., eds.), Macmillan Publishing Co., New York, pp. 177-227

McCown B.H. \& Sellmer J.C. (1987) General media and vessels suitable for woody plant culture. In: Cell and Tissue Culture in Forestry, Vol. 1. General Principles and Biotechnology. (Bonga J.M. \& Durzan D.J., eds.), Martinus Nijhoff Publishers, Dordrecht, pp. 4-16

Murashige T. \& Skoog F. (1962) A revised medium for rapid growth and bioassay with tobacco tissue cultures. Physiol. Plant. 15, 473497

Wang P.J. \& Hu C.Y. (1980) Regeneration of virus-free plants through in vitro culture. In: Adv. Biochem. Eng., Vol. 18. Plant Cell Culture II. (Fiechter A., ed.), Springer-Verlag, Berlin, pp. 61-99 